\title{
Politically Palatable Parity: What the United States Can Learn From France in AChieving a More Representative Democracy
}

\author{
Nicholas J. D’Angelo \\ St. John's University School of Law, New York, USA \\ njd0815@gmail.com
}

D’ANGELO, Nicholas J. Politically Palatable Parity: What the United States Can Learn From France in Achieving a More Representative Democracy. International and Comparative Law Review, 2016, vol. 16, no. 2, pp. 29-47. DOI: 10.1515/ iclr-2016-0013.

\begin{abstract}
Summary: The United States considers itself a world superpower in many realms, but equality in political representation is not one of them. Currently, female representation in the United States Congress hovers around nineteen-percent, placing the United States in league with nations that have historically oppressed women, including Kenya and Tajikistan. While other, more infant, democracies have utilized political quotas as a means to increase female political involvement, the United States' maintains a tradition of formal equality and neutralism. Long-standing precedent remains suspicious of anything resembling a quota. However, France faced a similar dilemma, unable to increase female representation due to a tradition of universalism. Working within its constitutional confines, France adopted parity in an attempt to achieve "perfect equality." This paper argues that the United States may be able to use France as an example, thus potentially increasing female representation through a parity system that respects the traditions of our Constitution.
\end{abstract}

Keywords: parity, France, equal representation, representative government, laicite, feminism, female representation in government, equal rights.

\section{Introduction}

In November 2016, Governor Maggie Hassan, New Hampshire's top Democrat, challenged Senator Kelly Ayotte, the state's top Republican, in an historic female-versus-female contest. ${ }^{1}$ In fact, it was only the fifteenth time in American history that such a contest has happened. ${ }^{2}$ Still, 2016 was not a record setting

1 ROSS, Janell. Women are Stepping Up in Most Major 2016 Senate Races. Available at: https://www.washingtonpost.com/news/the-fix/wp/2015/05/28/women-are-stepping-up-inmost-major-2016-senate-races/.

2 OSTERMEIER, Eric. Hassan vs. Ayotte Sets Up $15^{\text {th }}$ U.S. Senate Matchup Between Female Nominees. Available at: http://editions.lib.umn.edu/smartpolitics/2015/10/07/hassan-vsayotte-sets-up-15th-us-senate-matchup-between-female-nominees/. 
year for women in government. ${ }^{3}$ Despite women serving in Congress for nearly a century, and a major party nominating a woman for president, female political representation in the United States remains stagnate. ${ }^{4}$ This places the United States at an awkward crossroads.

More infant governments, such as Afghanistan and Pakistan, have instituted political quotas in order to ensure greater female representation. ${ }^{5}$ In fact, countries as diverse as those in Europe and Africa have instituted similar policies as the most efficient way to increase women participating in national governments. ${ }^{6}$ However, the United States is not an infant nation and our country maintains a lingering suspicion of raw number quotas, specifically in the realm of racial affirmative action. ${ }^{7}$ Still, the United States can learn from similarly situated nations, such as France, in addressing political parity through more palatable means. French universalism, which stresses formal equality, is similar in many ways to American neutralism. ${ }^{8}$ Despite this constitutional structure, France has still been able to institute parity measures through constitutional amendments.

This paper argues that the United States may be able to use France as a model, adopting a similar constitutional mandate in order to ensure greater female representation without violating decades of judicial precedent. Part I outlines the different quota systems, the supporting and critical arguments of such programs, and the necessity of increasing female political participation globally. Next, Part II discusses France's history of adopting political parity through a constitutional

3 CLEARFIELD, Alex. 2016 Won't Beat Many Records for Women in the Senate. Available at: http://www.rollcall.com/news/politics/senate-women.

4 COHN, Laura. The U.S. Made Zero Progress in Adding Women to Congress. Available at: http://fortune.com/2016/11/10/election-results-women-in-congress/.

5 BEYDOUN, Khaled A. Fast Tracking Women into Parliamentary Seats in the Arab World. The Southwestern Journal of International Law, 2011, vol. 75, iss. 63, p. 67 (arguing "the (generally) autocratic and hyper-patriarchal contexts in the Arab world require a fast track quota approach to speedily integrate women into parliament and expedite regional consciousness around gender equality"); BUSH, Sarah Sunn. International Politics and the Spread of Quotas for Women in Legislatures. International Organization, 2011, vol. 65, iss. 103, pp. 126-27 (explaining that Afghanistan, in particular, was influenced by international actors. When the new constitution was formed in 2004, it reserved 27 percent of seats in the lower house, and 17 percent of seats in the upper house, for women); KROOK, Mona Lena. Quotas for Women in Politics: Gender and Candidate Selection Reform Worldwide. Oxford: Oxford University Press, 2010, p. 57 (recounting that Pakistan has a long history of reserving seats for female representation dating back to British colonial rule in the 1930s and Pakistan's own constitutional reforms after independence in the 1950s).

6 Proportion of seats held by women in national parliaments (\%), World Bank (2011-2015). Available at: http://data.worldbank.org/indicator/SG.GEN.PARL.ZS.

7 MCDONAGH, Eileen. The Motherless State: Women's Political Leadership and American Democracy. University of Chicago Press, 2009, p. 215 (describing America's troubled history with quotas).

8 MARIN, Ruth Rubio. A New European Parity-Democracy Sex Equality Modern and Why It Won't Fly in the United States. The American Journal of Comparative Law, 2012, vol. 60, iss. 99, p. 122. 
amendment and the justifications for instituting the policy. Then, Part III analyzes the constitutional challenges within the United States, including Equal Protection Clause ${ }^{9}$ challenges and First Amendment ${ }^{10}$ protections. Finally, Part IV suggests different approaches the United States may use in achieving parity, such as setting long-term goals or ratifying a constitutional amendment.

\section{Political Quotas Generally}

\subsection{Different Models for Political Quotas}

Over one hundred countries around the world have either instituted gender quotas or debated it over the last several decades. ${ }^{11}$ When female membership in representative bodies does not increase organically, quotas help to ensure that result at varying rates. The rate depends on the choice of quota system. Traditionally, three quota systems exist. First, "reserved seats" set aside a certain number of parliamentary seats for women through constitutional reform. ${ }^{12} \mathrm{Sec}-$ ond, "party quotas" increase female candidates within a particular party through voluntary party reforms. ${ }^{13}$ Finally, "legislative quotas" require parties to field a certain number of female candidates through constitutional or legal reforms. ${ }^{14}$ These quota systems usually work to ensure that women represent a "critical minority," equal to 30 to 40 percent of the seats. ${ }^{15}$

Still, other potential systems are not satisfied with achieving a "critical minority," instead working towards "perfect equality." ${ }^{16}$ Political parity, an alternative from quotas that shares a similar goal, is based on the theoretical equality that has bogged down the progress of such nations as France and the United States. Unlike quotas, which institute rigid percentages as the gauge for equality, parity requires an equal number of male and female candidates as a move towards equal opportunity. ${ }^{17}$

9 U.S. Const. amend XIV.

10 U.S. Const. amend. I.

11 KROOK, Mona Lena. Candidate Gender Quotas: A Framework Analysis. The European Journal of Political Research, 2007, vol. 46, iss. 367, p. 367.

12 Id.

13 Id.

14 Id.

15 DAHLERUP, Drude. Increasing Women's Political Representation: New Trends in Gender Quotas. In BALLINGTON, Julie, and KARMAN, Azza (eds.) Women in Parliament: Beyond Numbers. International Idea, 2006, p. 142. "Critical minority" was defined by a United Nations Development Programme report in 1995, which viewed the 30 percent mark as the minimum "that enables women to exert meaningful influence on policies." Human Development Report, 1995. Available at: http://hdr.undp.org/sites/default/files/ reports/256/hdr_1995_en_complete_nostats.pdf.

16 Commentators disagree over whether to refer to this as "fifty-fifty" equality. Vogel-Polsky, Eliane. Les impasses de l'égalité ou pourquoi les outils juridiques visant à l'égalité des femmes et des hommes doivent être repensés en terme de parité. 1 Parité-Infos 9, 1994.

17 Opello, Katherine A. R. Gender Quotas, Parity Reform, and Political Parties in France. 
Overall, because any implementation of gender quotas has been a relatively recent phenomenon, it is difficult to judge success. ${ }^{18}$ However, the focus of the United Nations and other global organizations has been on post-conflict countries. ${ }^{19}$ While it is true that those nations represent easier tasks in instituting quotas or parity because of the novelty of their constitutions, they are not the only nations in need of international pressure to act. Interestingly, many postconflict nations actually have the greatest numbers of female representation in government, including Rwanda (63.8\%), South Africa (42\%), and Afghanistan $(27.7 \%) .{ }^{20}$ Therefore, increased international pressure should be applied to developed nations and world powers alike in order to ensure greater progress.

\subsection{Support and Criticism for Gender Quotas}

Quotas, as well as other strategies to achieve equality, have sparked an impassioned debate across the world. Proponents point to the benefits of encouraging and expanding female political representation. Meanwhile, critics condemn gender quotas, and their cousin "parity," ${ }^{21}$ for violating formal equality and representing a slippery slope towards quotas for all interest groups.

First, proponents argue there is a need to increase female representation across the world. After all, parliamentary bodies are meant to represent the societies that elect them and by increasing female membership in representative bodies, a different perspective is provided. ${ }^{22}$ Moreover, the debate is diversified, channeling interests and experiences that may never have had a seat at the table. This diversified debate and unique perspective leads to new policies, which help to benefit interested groups that might have previously been ignored. ${ }^{23}$ In addi-

Oxford: Lexington Books, 2006, p. 1.

18 Davidson-Schmich, Louise K. Implementation of Political Party Gender Quotas: Evidence from the German Lander 1990-2000. Party Politics, 2006, vol. 12, iss. 212.

19 Gender and Post-Conflict Reconstruction: Lessons Learned from Afghanistan. Available at: http://www.un.org/womenwatch/ianwge/taskforces/ParisJoint_Workshop_Report_final. pdf; KLOT, Jennifer F. Women and Peacebuilding. Available at: http://www.un.org/en/ peacebuilding/pdf/doc_wgll/wgll_backgroundpaper_29_01_08.pdf.

20 Women in National Parliaments: World Classification. Available at: http://www.ipu.org/ wmn-e/classif.htm.

21 Parity is difficult to define, but is best thought of as "perfect equality," distinct from quotas, which focus instead on reaching a "critical minority." Vogel-Polsky, Eliane. Les impasses de l'égalité ou pourquoi les outils juridiques visant à l'égalité des femmes et des hommes doivent être repensés en terme de parité. Parité-Infos, 1994, vol. 1, p. 9 ("Parity does not mean 50-50. Parity is demanded in the name of equal status, and not in the name of representing a minority.").

22 PANDE, Rohini and FORD, Deanna. Gender Quotas and Female Leadership: A Review. Available at: http://scholar.harvard.edu/files/rpande/files/gender_quotas_-_april_2011. pdf ("[A] lack of female leadership translates directly into an underrepresentation of women's interests in policy decisions. Increasing the proportion of female leaders through quotas can improve representation of women's policy interests.").

23 RHODE, Deborah L. and PACKEL, Amanda K. Diversity on Corporate Boards: How Much 
tion to the positive results that may occur, many argue that increasing female representation is necessary through a social rationale and progressive theory. ${ }^{24}$

Further, without quota-style reforms in place, women are less likely to seek elected office in the first place, thus depriving society of their valuable input. According to the Brookings Institution, women are less likely than men to consider running for office, to think they are qualified to run, to actually run, or to run if asked. ${ }^{25}$ Even more critical, women who do run, win, and serve are less likely to stay, making their presence temporary. ${ }^{26}$ Additionally, in the realm of voluntary party quotas, political parties are more likely to implement their own quotas if opposing parties have already done so. ${ }^{27}$ This represents a "race to the top" model of achieving the desired result. Therefore, proponents argue, reforms to force the increase of female representation become necessary.

Alternatively, opponents counter that anything resembling a quota is superficial, violates the ideals of equal opportunity, and will lead to more quotas for more interest groups. In the United States and Europe, resistance to quotas has been mostly defined in terms of formal equality. ${ }^{28}$ In this sense, quotas violate gender neutrality, which has been at the focus of numerous democratic documents in the Western hemisphere. ${ }^{29}$ As Rubio-Marin writes, resistance is "relat-

Difference Does Difference Make? The Delaware Journal of Corporate Law, 2014, vol. 39, iss. 377, p. 384 (citing recent studies showing a positive correlation between female membership on corporate boards and overall performance due to the diverse views). NELSON, Eboni S. Examining the Costs of Diversity. The University of Miami Law Review, 2009, vol. 63, iss. 577, p. 593 ("In Sweatt [v. Painter, 339 U.S. 629 (1950)] and McLaurin [v. Oklahoma State Regents for Higher Education, 339 U.S. 637 (1950)] . . . we see the Court's allusion to the democratic and social benefits flowing from a racially diverse student body.").

24 BUTLER, Seletha R. Butler. All on Board! Strategies for Constructing Diverse Boards of Directors. The Virginia Law and Business Review, 2012, vol. 7, iss. 61, p. 75 (arguing "upper echelons" of organizations "should reflect the base").

25 LAWLESS, Jennifer and FOX, Richard. Why Are Women Still Not Running for Public Office? Available at: http://www.brookings.edu/ /media/research/files/papers/2008/5/womenlawless-fox/05_women_lawless_fox.pdf.

26 Id. FOX, Richard L. and LAWLESS, Jennifer L. Entering the Arena? Gender and the Decision to Run for Office. The American Journal of Political Science, 2004, vol. 48, p. 264 (arguing that "vestiges of traditional sex-role socialization" explains why women either do not run or do not remain in elective office).

27 KROOK, supra note 11, at 372.

28 Opponents of parity encompass a diverse array of actors, encompassing everyone from conservatives and neoclassical liberals to constitutional originalists and incumbent male elected officials. Põim, Maari. Out of the Deadlock: Tackling the Backlash of Gender Equality with Progressive Tools. Available at: http://www.feps-europe.eu/assets/55a1805a-f81a4b77-9249-f945dde0cc3c/policy-brief-genderpdf.pdf.

29 NATELSON, Robert. A Woman as President? The Gender-Neutral Constitution. Available at: https://www.washingtonpost.com/news/volokh-conspiracy/wp/2015/10/28/a-womanas-president-the-gender-neutral-constitution/. SAPHIRE, Richard B. Judicial Review in the Name of the Constitution. The Dayton University Law Review, 1983, vol. 8, iss. 745, pp. 796-97. 
ed to the stronger U.S. individualist tradition and its faith in both autonomy and meritocracy as expressed through the free functioning of the market and of social forces." ${ }^{30}$

Moreover, opening up a certain number of seats for women means that other interest groups are likely to demand reserved seats as well, and will have precedent to rely on. Among the most prominent candidates for these additional special classifications would be religious groups. ${ }^{31}$ Other scholars have argued that viewpoint would satisfy the political and social diversity goals expressed by quota rationales. ${ }^{32}$ While such thinking seems to violate a reasonable understanding of the purpose and scope of quotas, the arguments demonstrate the theoretical conclusions that may ultimately be drawn.

Finally, the United States has a long history of suspicion with quotas. Even policies merely resembling a quota are likely unconstitutional..$^{33}$ Furthermore, scholars have argued that even if a quota were constitutional, affirmative action simply does not work..$^{34}$ Instead, affirmative action programs, like quota systems, represent an inorganic and superficial attempt at equality. These critical arguments leave the United States with one last possibility: political parity.

\subsection{By the Numbers: Why the United States Must Do Something}

The United States must do something to increase female representation in government. Women represent 50.4 percent of the U.S. population, ${ }^{35}$ women comprise 47 percent of the U.S. workforce, ${ }^{36}$ and 10 million more women voted in the 2008 presidential election than men. ${ }^{37}$ Despite these figures, the United States shares company with Saudi Arabia, Kenya, and Tajikistan, all with female

30 Marin, Ruth Rubio. A New European Parity-Democracy Sex Equality Modern and Why it Won't Fly in the United States. The American Journal of Comparative Law, 2012, vol. 60, iss. 99, p. 121.

31 CHEN, Jim. Diversity in a Different Dimension: Evolutionary Theory and Affirmative Action's Destiny. The Ohio State Law Journal, 1998, vol. 59, iss. 811, p. 862 ("It is hard to imagine why religious diversity should warrant less solicitude than racial diversity. Free exercise is as much a part of the Constitution as equal protection.").

32 LINDGREN, James. Conceptualizing Diversity in Empirical Terms. The Yale Law and Policy Review, 2005, vol. 23, iss. 5, p. 6.

33 Gratz v. Bollinger, 539 U.S. 244, 269 (2003) (invalidating a diversity plan that assigned applicants points for particular characteristics because it too closely resembled a "quota").

34 DELGADO, Richard Delgado. Affirmative Action as a Majoritarian Device: Or, Do You Really Want to Be a Role Model? The Michigan Law Review, 1991, vol. 89, iss. 1222, p. 1224.

35 Table: Population, Female (\% of total), 2011-2015. Available at: http://data.worldbank.org/ indicator/SP.POP.TOTL.FE.ZS.

36 Women in the Labor Force in 2010, U.S. Department of Labor. Available at: http://www.dol. gov/wb/factsheets/qf-laborforce-10.htm.

37 STARK, Caitlin. By the Numbers: Women Voters. Available at: http://www.cnn. com/2012/10/25/politics/btn-women-voters/. 
political representation hovering around 19 percent. $^{38}$ The numbers speak for themselves. Therefore, something must be done to address the imbalance.

\section{French Political Parity}

\subsection{French Universalism and American Neutralism}

Similar to the United States, France has a historical political philosophy focused on formal equality before the law that seems at odds with the rigidity of quotas. From the earliest expressions of French democracy, political thinkers rejected female participation outright. For example, while scholars quibble over the philosophy of Jean-Jacques Rousseau, ${ }^{39}$ most at least agree that his ideals for the freedom of men rested on an insubordinate status for women. ${ }^{40}$ The philosophy of Rousseau and other similar French intellectuals served as an inspiration for the political currents of the French Revolution.

The Declaration of the Rights of Man and of the Citizen of 1789 addressed only the male population, granting them equal rights under Article 1 and the right to engage in government under Article $6 .{ }^{41}$ Even far-left socialist thinkers, such as Proudhon, ${ }^{42}$ felt strongly about feminine exclusion from public life. ${ }^{43}$ Moreover, unlike other global democracies, such as the United States and the United Kingdom, France refused to give women the right to vote until 1944. ${ }^{44}$

38 Women in National Parliaments: World Classification. Available at: http://www.ipu.org/ wmn-e/classif.htm.

39 One of the most renowned political theorists, Rousseau influenced the Enlightenment in France and across Europe. His philosophy also affected the overall development of modern political and educational thought. SCOTT, John T. (ed.). The Major Political Writings of Jean-Jacques Rousseau. Chicago: The University of Chicago Press, 2012.

40 WEISS, Penny. A Gendered Community: Rousseau, Sex, and Politics. New York: New York University Press, 1993 (arguing Rousseau's philosophy rests on a hierarchical political theory); PATEMAN, Carole. The Disorder of Women: Democracy, Feminism and Political Thought. Stanford: Standford Univesity Press, 1989 (claiming Rousseau's philosophy of freedom for men depends on the servitude of women); ICE, Tamela. Resolving the Paradox of Jean-Jacques Rousseau's Sexual Politics. New York: University Press of America, 2009 (arguing that, to Rousseau, women are a means to the equality of men).

41 Declaration of the Rights of Man 1789, Art. 1, 6. This can be compared to America's Declaration of Independence, which stated, "All men are created equal." Declaration of Independence (emphasis added).

42 Pierre-Joseph Proudhon was a French politician and philosopher. He is regarded as the first person to declare himself an anarchist and is considered one of the ideology's most influential theorists. WOODCOCK, George. Pierre-Joseph Proudhon: A Biography. Black Rose Books, 1987.

43 MOSS, Claire Goldberg. French Feminism in the Nineteenth Century. Albany: State University of New York Press, 1984, p. 156.

44 SEPPALA, Nina. Women and the Vote in Western Europe. Available at: http://www.idea. int/publications/voter_turnout_weurope/upload/chapter\%204.pdf. It seems to have taken much longer to gain the right to vote in France than in other Western European countries. For example, Finland granted women the right to vote in 1906. Still, Liechtenstein did not 
Perhaps even more puzzling was "the relative lack of awareness of French women of questions concerning their civil rights" during this critical period. ${ }^{45}$ Unlike in the United States or the United Kingdom, there was no great suffrage movement in France. ${ }^{46}$

Moreover, France has had a longstanding adherence to national sovereignty. For example, the Constitution of 1958 embraces the indivisibility of the republic, thus limiting separate social categories. ${ }^{47}$ This formal equality is also related to the French political theory of laïcité, which embraces formal secularism by disallowing other forms of identification. ${ }^{48}$ In other words, "French citizen" becomes the penultimate classification. ${ }^{49}$ The problem, of course, is that while national sovereignty intends formal equality, it lacks the means to fully ensure that result. This may explain why female empowerment in France has been so slow, and why parity reforms were deemed necessary in the late twentieth century.

\subsection{The French Adoption of Parity}

By the beginning of the Fifth Republic, France realized it had an equality problem. Like other nations, France began to more fully recognize particular women's rights, including access to contraception in $1967^{50}$ and abortion in 1975. ${ }^{51}$ Based on this newfound recognition, the French parliament began adopting affirmative action quotas to ensure equal representation for women in $1982 .{ }^{52}$ The new provisions, passed by a National Assembly vote of 476 to $4,{ }^{53}$ prohibited candidate lists for local elections from including more than 75 percent of candidates of the same sex. ${ }^{54}$

provide women suffrage until 1984. Id.

45 LENOIR, Noelle. The Representation of Women in Politics: From Quotas to Parity in Elections. International and Comparative Law Quarterly, 2001, vol. 50, iss. 217, pp. 223-24. The basis for the author, a member of the Conseil Constitutionnel, is an empirical evaluation of the French suffrage movement compared to that of the United States and Great Britain. Id.

$46 I d$. at 224.

47 Constitution of $1958, \$ 2$.

48 DALY, Eoin. Laïcité, Gender Equality and the Politics of Non-Domination. The European Journal of Political Theory, 2012, vol. 11, p. 292.

49 Id.

50 MILLARD, Eric. Paritary Rights for Women and Universal Human Rights in France. IUS Gentium, 2001, vol. 7, iss. 1, p. 11.

51 Id.

52 Id. at 13.

53 LENOIR, supra note 45, at 236.

54 MILLARD, supra note 50, at 14. 
However, by November of that year, the Conseil Constitutionnel ${ }^{55}$ held the parity reforms unconstitutional. ${ }^{56}$ The court reasoned that quotas violated principles of French universalism: "[A]ny division or categorization of the electorate, or of eligible persons, would be against these principles, which have a constitutional force." ${ }^{57}$ The court relied on Article 3 of the Constitution of 1958 and Article 6 of the Declaration of the Rights of Man, which both made clear that equality precluded "any division by categories of voters and candidates." ${ }^{58}$ With it becoming increasingly difficult to fit increased female representation within the rigid confines of theoretical principle, hope for increasing female representation languished.

It was not until the 1990s that renewed interest in female representation reseized national politics. Since the 1982 decision, the debate had been reframed. Proponents no longer argued for increasing female representation by percentages, unequally applied, but by full and equal measure:

Parity could be viewed as true equality, or "concrete" equality, that would not discriminate, but simply realize the duality of the human race. Understood in this way, parity would not contravene the principle of universalism or the universality of rights. ${ }^{59}$

Quite simply, according to some advocates, a democracy without women is not a democracy at all. ${ }^{60}$

Parity would represent "perfect equality," not some random "critical minority" defined by committee and imposed by government. In 1999, the Constitution of 1958 was amended to provide: "The law shall promote the equal access of men and women to electoral power and elected position." 61 The goal was no longer to advance women, which had been the strategy in 1982. Instead, the

55 The "Constitutional Council" is France's highest authority on constitutional issues. However, its powers and scope differ greatly from its American counterpart, the U.S. Supreme Court. DAVIS, Michael H. The Law/Politics Distinction, the French Conseil Constitutionnel, and the U.S. Supreme Court. The American Journal of Comparative Law, 1986, vol. 34, p. 45. MORTON, F.L. Judicial Review in France: A Comparative Analysis. The American Journal of Comparative Law, 1988, vol. 36, p. 89.

56 LENOIR, supra note 45, at 236. It is interesting to note that the term "parity" was never used in the legislation, but was commonly used by the French press. However, the specificity of the legislation, focused on a ceiling percentage, seems too specific to truly be considered parity. Id.

57 CC Decision 82-146 DC Nov. 18, 1982.

58 Id. Article 3 of the 1958 Constitution stated: "National sovereignty belongs to the people. No section of the people nor any individual may arrogate its exercise to itself." Constitution of 1958, Art. 3.

59 MILLARD, supra note 50, at 15.

60 GASPARD, Françoise, et. al. Au Pouvoir Citoyennes! Liberte, Eqalite, Parite. Editions du Seuil, 1992, p. 129.

61 SUK, Julie. Gender Parity and State Legitimacy: From Public Office to Corporate Boards. The International Journal of Constitutional Law, 2012, vol. 10, iss. 449, p. 455. 
purpose became advancing the nation through diversity as a social good. As Suk writes, "The imagined beneficiary of gender parity was no longer the new elected female legislator, but the republic itself." ${ }^{2} 2$ Therefore, through renewed activism by interested parties, France was able to amend its Constitution in order to provide for parity as a means to truly increase female representation at the municipal and national levels.

\subsection{The Results of French Parity}

The results of the constitutional amendment have been mixed. French election practices, which range from proportional systems for municipal and regional elections to single candidate systems for National Assembly elections, make the implementation of parity difficult to measure. ${ }^{63}$ Still, in 2001, the first election year in which the parity law was effective, female representation in the Senate tripled to 21.5 percent. ${ }^{64}$ Municipal improvements were even greater. ${ }^{65}$ During that election, 38,000 women were elected to local councils, representing 47.5 percent of the nation's municipal council members. ${ }^{66}$

However, in other areas, the numbers tell a different story. For example, in head-to-head national elections in 2002, women fared much worse. In the first round of voting for the National Assembly, women represented 38.5 percent of the candidates, but that fell to 23.9 percent by the second round, and only 71 women were ultimately elected. ${ }^{67}$ Moreover, those elected accounted for only 12.3 percent of the legislature, a modest gain for such a revolutionary reform. ${ }^{68}$ Perhaps even more concerning, in the elections since the first tests in 2001 and 2002, the progress stagnated..$^{69}$ After the 2008 Senate elections, the percentage of female representation actually decreased. ${ }^{70}$ Of course, this disconnect causes concerns and raises questions. Why isn't parity working?

Observers note several possible explanations for the trend. First, in the National Assembly elections, less experienced women were placed against male

62 Id.

63 ROSENBLUM, Darren. Parity/Disparity: Electoral Gender Inequality on the Tightrope of Liberal Constitutional Traditions. The U.C. Davis Law Review, 2006, vol. 39, iss. 1119, p. 1145.

64 Id. at 1147.

65 Id.

66 SINEAU, Mariette. Institutionalizing Parity: The French Experience. Available at: http:// docplayer.net/17700607-Institutionalizing-parity-the-french-experience.html.

67 ROSENBLUM, supra note 63, at 1148 .

68 FRECHETTE, Guillaume R., MANIQUET, Francois \& MORELLI, Massimo. Incumbent's Interest and Gender Quotas. The American Journal of Political Science, 2008, vol. 52, p. 891.

69 LEWIS, Priscilla. Gender Parity Laws in France Have Been Undermined by Electoral Reforms which Work Against Female Candidates. Available at: http://blogs.lse.ac.uk/europpblog/2013/09/13/gender-parity-laws-in-...ermined-by-electoral-reforms-which-workagainst-female-candidates/.

70 Id. 
candidates with greater resources, thus resulting in high losses. ${ }^{71}$ Even if women are on the ballot in an equal proportion to men, they must still be given the resources to effectively compete. ${ }^{72}$ Other commentators have blamed more sinister motives. For example, subsequent reforms have made it more difficult for parity to fully take effect. In 2003, the Raffarin reforms changed the method of Senate and European Parliament elections from a national constituency to eight regional constituencies. ${ }^{73}$ Because parity relies on candidate lists, this indirectly impacts the system's progress:

In [the] situations where a party receives only one or an uneven number of seats in a district, an imbalance occurs in the number of male and female candidates who actually fill those seats within their party. Although this imbalance is slight with one national constituency, as was the case in the 1999 elections to the $\mathrm{EP}$, the potential for such bias against female candidates increases as the number of districts increases. ${ }^{74}$

Therefore, even if parity is written into the constitution, it is ineffective unless the system in which it operates is also fair.

Alternatively, scholars have suggested that male politicians never actually intended parity to occur, instead crafting a political illusion. ${ }^{75}$ Male incumbents overwhelmingly voted for candidate lists, the arguments goes, because it was more desirable than true parity, which required women to actually hold office. ${ }^{76}$ In this way, male politicians can appear progressive, but still maintain their seats through the next election. ${ }^{77}$

In the end, it may take time for women elected at the municipal level to gain greater experience before being elevated to national offices. At first glance, parity seems to have had a promising start in France, laying the foundation for greater female representation in the future. However, it is important to remember that

71 ROSENBLUM, supra note 63, at 1148 .

72 This should echo President Lyndon Johnson's famous commencement address at Howard University in 1965, where he spoke on civil rights: "But freedom is not enough. You do not wipe away the scars of centuries by saying: Now you are free to go where you want, and do as you desire, and choose the leaders you please." JOHNSON, Lyndon. Commencement Address at Howard University: To Fulfill These Rights. In 2 Public Papers of the Presidents of the United States: Lyndon B. Johnson, 1965. Washington, D.C.: Government Printing Office 1966, pp. 635-40.

73 SOUTHWELL, Priscilla. Gender parity thwarted? The effect of electoral reform on Senate and European Parliamentary Elections in France, 1999-2011. 11 French Politics 169, 172, 2013.

74 Id.

75 FRECHETTE, supra note 68, at 892. MURRAY, Rainbow, KROOK, Mona Lena \& OPELLO, Katherine A. R. Why Are Gender Quotas Adopted?: Party Pragmatism and Parity in France. Political Research Quarterly, 2013, vol. 65, iss. 529, p. 530 (arguing that parity adoption is self-interested because political parties benefit from bias against female candidates).

76 FRECHETTE, supra note 68, at 892-93.

77 Id. 
opponents to parity have developed creative methods to avoid its successful implementation. ${ }^{78}$

\section{Constitutional Challenges to Parity in the United States}

Parity may be a worthy endeavor that provides true progress for female representation in government. However, it is not without its challenges. Most notably, the U.S. Supreme Court has long articulated a suspicion of anything resembling a quota. Assumedly, this would include gender quotas for women in government.

Even without resorting to the rigidity of a quota system, parity would encounter demanding constitutional inquiry. First, parity would be challenged for violating the Equal Protection Clause. Second, parity would be challenged for violating the First Amendment right of political association. In facing these challenges, courts will have to rely on analogies to previously decided issues of affirmative action and free speech in determining the constitutionality of parity.

\subsection{Equal Protection Clause Challenges}

The Supreme Court has never ruled on an affirmative action case for gender, but it is appropriate to analogize gender with affirmative action cases for race because both are immutable characteristics subjected to discrimination. ${ }^{79}$ Additionally, there is a wealth of case law addressing gender affirmative action programs from circuit courts and state courts that provide fruitful illustrations.

Any discussion on affirmative action must necessarily begin with Regents of the University of California v. Bakke. ${ }^{80}$ In that case, the Court struck down a medical school's admissions policy reserving sixteen of 100 seats for "disadvantaged" applicants, specifically racial minorities. ${ }^{81}$ The court rejected the University's purpose to provide preferential treatment, to aid victimized groups, and to improve healthcare services to underserved communities. ${ }^{82}$ However, the court stated that the attainment of diversity was a constitutionally permissible state interest. ${ }^{83}$ Citing a wide array of Supreme Court and lower court decisions, the

78 Again, a comparison to civil rights is appropriate. Despite the Fourteenth and Fifteenth Amendments being ratified between 1865 and 1870, it took almost a century for them to be fully enforced through the Civil Rights Act of 1964 and the Voting Rights Act of 1965. ROSENBERG, Gerald N. The 1964 Civil Rights Act: The Crucial Role of Social Movements in the Enactment and Implementation of Anti-discrimination Law. St. Louis University Law Journal, 2004, vol. 49, p. 1147.

79 MAYERI, Serena. Reconstructing the Race-Sex Analogy. The William \& Mary Law Review, 2008, vol. 49, iss. 1789, p. 1796.

80438 U.S. 265 (1978).

81 Id. at 279.

82 Id. at 307-09.

83 Id. at 311. 
Court emphasized the societal benefit of the "multitude of tongues." 84 Still, the University's sole reliance on race did not fit this criterion. ${ }^{85}$

In 2003, the Supreme Court maintained that diversity was a compelling government interest that justified racial affirmative action programs. In Grutter $v$. Bollinger, ${ }^{86}$ the court upheld a law school admissions program that used race as a factor to achieve a "critical mass" ${ }^{\text {" } 7}$ of minority students. ${ }^{88}$ In so deciding, the court noted that the state had a compelling interest in providing a more diverse student body ${ }^{89}$ and that race was merely a "potential 'plus' factor" in the overall admission evaluation..$^{90}$ Therefore, societal diversity justified narrowly tailored affirmative action programs. ${ }^{91}$

While the Court has never ruled on gender-based affirmative action, some have speculated that because gender is held to only "intermediate scrutiny," 92 instead of the more exacting "strict scrutiny" for race, government programs directed towards gender may be easier to uphold. ${ }^{93}$ Justice Stevens, in his dissenting opinion in Adarand Constructors, Inc. v. Pena ${ }^{94}$ predicted such a situation. "[T] he government can more easily enact affirmative action programs to rem-

84 Id. at 312. U.S. v. Associated Press, 52 F. Supp. 362, 371 (S.D.N.Y. 1943) ("[The First Amendment] presupposes that right conclusions are more likely to be gathered out of a multitude of tongues, than through any kind of authoritative selection. To many this is, and always will be, folly; but we have staked upon it our all.").

85 Bakke, 438 U.S. at 315. "It is not an interest in simple ethnic diversity, in which a specified percentage of the student body is in effect guaranteed to be members of selected ethnic groups, with the remaining percentage an undifferentiated aggregation of students. The diversity that furthers a compelling state interest encompasses a far broader array of qualifications and characteristics of which racial or ethnic origin is but a single though important element." Id.

86539 U.S. 306 (2003).

87 Id. at 329.

88 Id. at 343.

89 Id. at 330-32 ("In order to cultivate a set of leaders with legitimacy in the eyes of the citizenry, it is necessary that the path to leadership be visibly open to talented and qualified individuals ...").

90 Id. at 334.

91 Id.

92 While strict scrutiny review for gender discrimination was originally adopted by the plurality opinion in Frontiero v. Richardson, 411 U.S. 677 (1973), subsequent cases did not adopt such a standard. In Craig v. Boren, 429 U.S. 190 (1976), the court outlined "intermediate scrutiny" as the proper review for sex classifications. This was more fully discussed by Justice Ginsburg in U.S. v. Virginia, 518 U.S. 515 (1996), and defined as an "exceedingly persuasive justification."

93 For example, in Califano v. Webster, the court applied intermediate scrutiny and upheld a section of the Social Security Act that gave preferential treatment to female retirees. See 430 U.S. 313, 317 (1977) ("Reduction of the disparity in economic condition between men and women caused by the long history of discrimination against women has been recognized as ... an important governmental objective.").

94515 U.S. 200 (1995) (Stevens, J., dissenting). 
edy discrimination against women than it can enact affirmative action programs to remedy discrimination against African Americans," he wrote, "even though the primary purpose of the Equal Protection Clause was to end discrimination against former slaves." ${ }^{25}$ Still, whether or not the court would uphold affirmative action provisions for women in politics under an intermediate scrutiny standard is an open question.

Several circuit courts have already wrestled with the affirmative action provisions for gender. Most courts have applied intermediate scrutiny review ${ }^{96}$ and most have upheld government intervention to limit discrimination based on gender. In Danskine v. Miami Dade Fire Department, ${ }^{97}$ the Eleventh Circuit addressed whether a county government could establish a quota to increase the number of female firefighters. ${ }^{98}$ The court held that the preferential program did not violate the Equal Protection Clause. ${ }^{99}$

In so holding, the court applied intermediate scrutiny because "genderbased governmental discrimination is reviewed less intensively than race-based discrimination." ${ }^{100}$ Applying this standard, the court reasoned that gender preference is allowed so long as it is "substantially related to an important governmental objective." ${ }^{101}$ Because less evidence is required for gender classifications than racial classifications, the government faced a significantly lower burden and exercised greater flexibility in enacting such programs. ${ }^{102}$ Consequently, while the court stressed that "an affirmative action plan may not go on forever," ${ }^{103}$ the

95 Id. at 247.

96 Eng'g Contractors Ass'n v. Metro. Dade Cnty., 122 F.3d 895, 929 (11th Cir. 1997) (applying intermediate scrutiny to a Florida "gender-conscious" affirmative action plan); Contractors Ass'n v. City of Phila, 6 F.3d 990, 1000-01 (3d Cir. 1993) (applying intermediate scrutiny to a gender-based government affirmative action program); Coral Constr. Co. v. King Cnty., 941 F.2d 910, 931 (9th Cir. 1991) (applying intermediate scrutiny to a government gender-based affirmative action program); Concrete Works of Colorado, Inc. v. City of Denver, 36 F.3d 1513, 1519 (10th Cir. 1994) (holding that intermediate scrutiny should apply to the gender classifications in a government affirmative action program). But see Conlin v. Blanchard, 890 F.2d 811, 816 (6th Cir. 1989) (finding that both race and sexbased classifications must be narrowly tailored to survive strict scrutiny review).

97253 F.3d 1288 (11th Cir. 2001).

98 Id. at 1289. The county instituted a "long-term" hiring goal of 36 percent women, which was challenged for violating Title VII and the Equal Protection Clause. Id.

99 Id.

$100 \mathrm{Id}$. at 1291

101 Id. at 1294 (quoting Eng'g Contractors Ass'n of S. Fla., Inc. v. Metro. Dade Cnty., 122 F.3d 895, 908 (11th Cir. 1997)).

102 Id.

$103 \mathrm{Id}$. at 1300. "Simply because discrimination in the form of affirmative action may be lawful at one point in time does not mean that such discrimination may be countenanced in the future." Id. See also Ensley Branch, NAACP v. Seibels, 31 F.3d 1548, 1570 (11th Cir. 1994) ("The goal of eliminating discrimination may justify some interim use of affirmative action, but affirmative action selection provisions are themselves a form of discrimination that cannot continue forever."). 
plan in this case was justified. ${ }^{104}$ Therefore, the Equal Protection Clause may not be violated.

\subsection{First Amendment Political Association Challenges}

Affirmative programs that increase the representation of women have also been challenged on First Amendment grounds, but these programs have still largely been upheld. ${ }^{105}$ For example, both the Republican and Democrat parties have long required that representatives of individual state parties to the national committees be equally divided between genders. ${ }^{106}$ However, unlike programs implemented by legislatures, the individual parties voluntarily adopt these rules. Therefore, when rules are promulgated governing party membership or delegate allocation, they generally have been determined to be within the parameters of the First Amendment. ${ }^{107}$

One of the clearest examples remains Marchiaro v. Chaney. ${ }^{108}$ In that case, members of the Democratic Party of Washington state sought injunctive relief against a state party rule that each county should have two delegates to the state convention, one delegate of each sex. ${ }^{109}$ Plaintiffs argued this rule violated the First Amendment. ${ }^{110}$ The court asserted that the proper test to determine a violation was whether the new rule placed a "substantial burden" on plaintiffs as they sought to achieve the "stated purpose and objectives" of the party. ${ }^{111}$ The court held that such a rule did not present that burden because the party itself had declared the purpose or objective to be equality among the genders. ${ }^{112}$

Through this reasoning, it seems logical that national and state parties could adopt similar rules that require slates of candidates for office to be proportionate between men and women. For example, if the party was nominating four 104 See Danskine, 253 F.3d at 1300.

105 See Bachur v. Democratic Nat'l Party 836 F.2d 837, 842-43 (4th Cir. 1987); Tashjian v. Republican Party of Conn., 479 U.S. 208, 210-11 (1986).

106 SCHENKEN, Suzanne O'Dea. From Suffrage to the Senate: An Encyclopedia of American Women in Politics. ABL-CLIO, Inc., 2009, p. 189-91. The Democratic Party follows an "Equal Division Rule," mandating that delegations to the national convention be composed of an equal number of men and women. While the Republican Party does not have such a rule, it does have Rule 14(d), which encourages state parties to implement similar rules. Republican National Committee Rule 14(d), 2012. Available at: https://cdn.gop.com/ docs/2012_RULES_Adopted.pdf.

107 Ripon Soc., Inc. v. Nat'l Republican Party, 525 F.2d 567 (D.C. Cir. 1975) (holding that an allocation formula awarding a greater number of delegates to the 1976 Republican Convention to states that previously voted for the Republican candidate in 1972 did not violate the First Amendment).

10890 Wash.2d 298 (1978).

109 Id. at 301.

110 Id. Plaintiffs also argued it violated Washington state's constitution, as well as the Equal Rights Amendment. Id. at 300.

$111 \mathrm{Id}$. at 310.

$112 \mathrm{Id}$. at 311. 
candidates for a village board election, two candidates would be required to be men and two would be women. Additionally, while it may be difficult to have both major parties adopt such rules, scholars argue that once one party adopts a proportionality rule, other competitor parties follow suit. ${ }^{113}$ This creates a "race to the top" for political parties, with each trying to become more competitive by achieving parity. ${ }^{114}$ Therefore, parity systems, if implemented properly, likely do not violate the First Amendment.

\section{Potential Solutions for the United States}

Parity remains a controversial topic, but it is necessary for the United States to begin the dialogue. There are a variety of avenues that could be used in order to achieve parity. Some are more constitutionally arduous, while others may be safer, but present more limited gains.

\subsection{Long-Term Target Goals}

A less aggressive strategy to increase female representation in politics is to set long-term goals. In order to achieve that goal, various programs would be implemented by outside groups in order to encourage women to become more involved in politics. For the strategy to be successful, organizers would need to raise money not only to publicize the issue and gain voter support, but also to fund female candidates who would likely face more entrenched male candidates. ${ }^{115}$

In terms of constitutional scrutiny, this strategy is safer than more robust strategies because it faces little legal opposition. ${ }^{116}$ Independent groups can advocate as much as they want for greater numbers of women in politics, including recruiting candidates, funneling money, and raising awareness. However, the downside to the strategy is substantial. Quite simply, it takes time. According to the Institute for Women's Policy Research, political parity will not be reached in Congress until 2121. ${ }^{117}$ These projections are based on a decades-long trend,

113 KROOK, supra note 11, at 372.

114 Id.

115 After all, this was the greatest weakness of the French parity system. Female candidates were propped up, but they simply did not have the resources to compete against more experienced, and better funded, male competitors. The challenge of funding also applies to men, but there are several reasons why obtaining financial resources is especially problematic for women, including: psychological barriers; networks; early money; family responsibilities; and scarcity of resources. BALLINGTON, Julie and MATLAND, Richard E. Political Parties and Special Measures: Enhancing Women's Participation in Electoral Processes. Available at: http://www.un.org/womenwatch/osagi/meetings/2004/EGMelectoral/ EP8-BallingtonMatland.PDF.

116 PETERS, Mary Ann and LAGON, Mark P. Gender Equality in Politics Still Far Away. Available at: http://www.baltimoresun.com/news/opinion/oped/bs-ed-women-political-participation-20150916-story.html.

117 Women's Share of Seats in Congress, 1960-2013 with Projection for Political Parity in 2121. 
which includes a period when women were largely shunned from public life. For that reason, it is easy to argue that this is an overestimate and that modern trends would increase that rate substantially. However, 2121 is still a long time to wait and the projection provides little motivation for a softer approach. ${ }^{118}$

\subsection{Constitutional Amendments}

A more aggressive tactic is to follow France's lead. Through this method, the United States would pass a constitutional amendment to overcome American neutrality in the same way France overcame universalism. Of course, this is a goliath task. However, it is, perhaps, the only way to ensure true change within a reasonable period of time.

There are comparisons that can be drawn from other constitutional reforms that have addressed women specifically. The first eventually became the Nineteenth Amendment, which provided women the right to vote. ${ }^{119}$ Proposed in 1878 , the amendment did not pass until over forty years later ${ }^{120}$ and even then it was challenged as unconstitutional, violating the rights of states that had not ratified it. ${ }^{121}$ Despite its inclusion in the Constitution, the amendment remains one of the least cited. ${ }^{122}$

A more modern example, but equally discouraging in terms of process, is the Equal Rights Amendment (ERA), proposed and rejected in the 1970s. ${ }^{123}$ In language, the ERA was nearly identical to France's amendment because it provided broad power to the legislature to redress disparities between the genders. ${ }^{124}$ While

Available at: http://www.iwpr.org/publications/pubs/women2019s-share-of-seats-in-congress-1960-2013-with-projection-for-political-parity-in-2121.

118 HENDERSON, Nia-Malika. Women will reach political parity in 2121. Why will it take so long? Available at: https://www.washingtonpost.com/blogs/she-the-people/ wp/2014/05/22/women-will-reach-political-parity-in-2121-why-will-it-take-so-long/.

119 BOZONELIS, Helen Koutras. A Look at the Nineteenth Amendment: Women Win the Right to Vote. Enslow Publishers, Inc., 2009, p. 60.

120 SARAT, Austin and KEARNS, Thomas R. History, Memory, and the Law. Ann Arbor: University of Michigan Press, 2002, p. 152.

121 The Nineteenth Amendment Questioned. Constitutional Review, 1921, vol. 5, p. 247. In Leser v. Garnett, an opinion authored by Justice Brandeis, the court affirmed the constitutionality of the Nineteenth Amendment by comparing its adoption to that of the Fifteenth Amendment. 258 U.S. 130, 136, (1922) ("This amendment is in character and phraseology precisely similar to the Fifteenth. For each the same method of adoption was pursued. One cannot be valid and the other invalid. That the Fifteenth is valid, although rejected by six states, including Maryland, has been recognized and acted on for half a century.").

122 SIEGEL, Reva B. She the People: The Nineteenth Amendment, Sex Equality, Federalism, and the Family. The Harvard Law Review, 2002, vol. 115, iss. 947, p. 950 (arguing that the Nineteenth Amendment has been "utterly excluded from the constitutional canon").

123 SOULE, Sarah A. and KING, Brayden G. The Stages of the Policy Process and the Equal Rights Amendment, 1972-1982. The American Journal of Sociology, 2006, vol. 111, iss. 1871, p. 1872.

124 The amendment only included three clauses, but the first two were the relevant parts: Sec- 
the ERA was passed by Congress, and gained the approval of thirty-five states, it fell short of the thirty-eight needed for ratification. ${ }^{125}$ Critics contend that an amendment similar to the ERA would be unnecessary because Title VII of the Civil Rights Act of 1964 has addressed many of the same issues with regards to discrimination. ${ }^{126}$ But what these observers miss are the issues that fall outside the scope of Title VII, but which Congress would be authorized to address with the power granted by a new constitutional amendment, such as parity rights. Therefore, a constitutional amendment would not be a "belts and suspenders" strategy of achieving equality, but a necessary and complete approach to overcome inequality in political representation.

Obviously, there are immense hurdles to overcome in providing a constitutional amendment, similar to France's amendment, which would allow political parity. Most interestingly is the lack of public awareness of or criticism towards the current state of affairs. Countries that have been able to increase female representation through similar means have been relatively young democracies ${ }^{127}$ that have suffered decades, if not centuries, of female oppression. Additionally, it is questionable whether it is appropriate to adopt a strategy simply because it has been used by other nations with different cultural ideologies than our own. ${ }^{128}$ While the United States has stressed neutralism, it also has encouraged an intimate individuality that is distinct from France's commitment to anonymity through a philosophy of "sameness." 229 Therefore, while a constitutional amend-

tion 1. Equality of rights under the law shall not be denied or abridged by the United States or by any State on account of sex. Section 2. The Congress shall have the power to enforce, by appropriate legislation, the provisions of this article. Proposed Amendments Not Ratified by the States. Available at: https://www.gpo.gov/fdsys/pkg/GPO-CONAN-1992/pdf/GPOCONAN-1992-8.pdf.

125 STEINER, Gilbert. Constitutional Inequality: The Political Fortunes of the Equal Rights Amendment. Washington, D.C: The Brookings Institution, 1985, p. 1. Interestingly, Justice Lewis Powell's concurring opinion in Frontiero v. Richardson noted that he would not join Justice Brennan's insistence on providing strict scrutiny to gender because of his assumption that the ERA would be ratified. 411 U.S. 677, 692 (Powell, J., concurring). Ironically, this may be the only reason gender is not granted more scrutiny as a suspect class, thus providing the flexibility that becomes necessary for greater government action, as acknowledged by Justice Stevens in Adarand. 515 U.S. 200 (1995) (Stevens, J., dissenting).

126 MACKINNON, Catharine A. Unthinking ERA Thinking. The University of Chicago Law Review, 1987, vol. 54, iss. 759, p. 770 (discussing the comparable results of the Equal Rights Amendment and Title VII).

127 For example, Iraq, Afghanistan, Rwanda, and Burundi, have all passed some sub-national or national law, or included a constitutional provision, for either quotas or parity. Country Overview, Quota Project: Global Database of Quotas for Women. Available at: http://www. quotaproject.org/country.cfm.

128 CASE, Mary Anne. Reflections on Constitutionalizing Women's Equality. The California Law Review, 2002, vol. 90, iss. 765, p. 774 (2002).

129 See id. at n. 106 ("I would not be inclined to have the United States follow the example of France, whose recent commitment to 'parity' may, I fear, be too direct a descendant of the French Revolutionary tendency to exclude only women when dissolving the three estates 
ment may be the best hope for the achievement of parity at a reasonable pace, it remains an overwhelming challenge that may be unlikely to succeed in the modern political environment.

\section{Conclusion}

Has the United States tied its own hands when it comes to gender equality? On an international scale, the United States ranks among the worst in terms of female representation in legislative bodies. A commitment to equality as neutralism has prevented the nation from enacting provisions that would remedy this inequality. However, just over a decade ago, France faced similar dilemmas, including a hostile court system and a revered but limited constitution. Therefore, by using France as a model, the United States can achieve parity in government without resorting to the disfavored practice of quotas.

into an otherwise undifferentiated citizenry."). 